\title{
Biochemical Basis for the Time-of-Day Effect on Glufosinate Efficacy against Amaranthus palmeri
}

\author{
Hudson K. Takano 1,2,*(D) and Franck E. Dayan 1,*(D) \\ 1 Department of Agricultural Biology, Colorado State University, Fort Collins, CO 80523, USA \\ 2 Mode of Action \& Resistance Center of Expertise, Crop Protection Discovery and Development, \\ Corteva Agriscience, Indianapolis, IN 46268, USA \\ * Correspondence: hudson.takano@corteva.com (H.K.T.); franck.dayan@colostate.edu (F.E.D.)
}

Citation: Takano, H.K.; Dayan, F.E. Biochemical Basis for the Time-of-Day Effect on Glufosinate Efficacy against Amaranthus palmeri. Plants 2021, 10, 2021. https://doi.org/10.3390/ plants10102021

Academic Editors: Hugh J. Beckie and Mithila Jugulam

Received: 15 July 2021

Accepted: 24 September 2021

Published: 26 September 2021

Publisher's Note: MDPI stays neutral with regard to jurisdictional claims in published maps and institutional affiliations.

Copyright: (c) 2021 by the authors. Licensee MDPI, Basel, Switzerland. This article is an open access article distributed under the terms and conditions of the Creative Commons Attribution (CC BY) license (https:// creativecommons.org/licenses/by/ $4.0 /)$.

\begin{abstract}
Glufosinate, a glutamine synthetase (GS) inhibitor, often provides variable weed control depending on environmental conditions such as light, temperature and humidity at the time of application. Midday applications normally provide improved efficacy compared to applications at dawn or dusk. We investigated the biochemical basis for the time-of-day effect on glufosinate efficacy in Amaranthus palmeri. GS1/GS2 gene expression and GS1/GS2 protein abundance were assessed in different parts (young leaves, old leaves, and roots) of plants incubated in the dark compared to those in the light. The turnover of GS total activity was also evaluated overtime following glufosinate treatment at midday compared to dusk application. The results suggest that GS in A. palmeri is less expressed and less abundant in the dark compared to in the light. Midday application of glufosinate under intense light conditions following application provide full control of A. palmeri plants. Consequently, these plants are unable to recover GS activity by de novo protein synthesis. Full activity of GS is required for complete inhibition by the irreversible inhibitor glufosinate. Therefore, glufosinate applications should always be performed in the middle of the day when sunlight is intense, to prevent weed escapes from the herbicide treatment.
\end{abstract}

Keywords: herbicide efficacy; glutamine synthetase; reactive oxygen species; enzyme turnover; mode of action; Palmer amaranth

\section{Introduction}

Glutamine synthetase (GS, E.C. 6.3.1.2) is one of the most abundant enzymes in plant cells [1]. It is essential for nitrogen metabolism because it catalyzes the conversion of glutamate and ammonium into glutamine. The two-step reaction begins with the ATPdependent phosphorylation of glutamate into $\gamma$-glutamyl-phosphate, followed by the incorporation of ammonium and formation of glutamine [2]. Two main isoforms have been identified in different cellular compartments: GS1 functions in the cytoplasm and GS2 is compartmentalized in the chloroplast [3]. While GS1 is involved in nitrogen assimilation and transport to other parts of the plant, GS2 recycles ammonium ions generated by other physiological processes in the plant [4]. Approximately, 60\% of the total ammonium consumed by GS2 come from the photorespiratory pathway [5].

The essential role of GS in plants makes the enzyme an interesting target for herbicides [6]. Inhibition of GS has catastrophic consequences to plant metabolism, leading to a massive accumulation of reactive oxygen species (ROS) due to impairment of photosynthesis and photorespiration [7]. Several experimental inhibitors have been discovered but only glufosinate has been developed as a commercial herbicide. Glufosinate is a racemic mixture of D- and L-phosphinothricin but only the L-isomer inhibits GS [8]. Studies on enzyme kinetics and crystal structure demonstrated that L-phosphinothricin is competitive with glutamate and non-competitive with respect to ammonium [9]. Inhibition of GS by glufosinate is irreversible, which is considered a suicide inhibition [2]. While GS isoforms 
have been extensively studied in model species, little is known about biochemical characteristics of GS isoforms in weeds. A better knowledge of such information can lead to improved weed management with GS-targeting herbicides like glufosinate.

Although glufosinate-based herbicides have been commercialized for more than 20 years, their use has increased in the last decade mainly to control glyphosate resistant weed species such as Amaranthus palmeri S. Watson [10]. Even with the significant increase in its use worldwide, a limited number of weeds have evolved resistance to glufosinate to date [11,12]. Moreover, genetically modified crops with resistance to glufosinate allows in-crop selective weed control as a post-emergence application $[13,14]$. In addition to row crops, glufosinate is also an important herbicide for perennial crops and non-agricultural areas due to its broad-spectrum activity on both monocot and dicot weed species [15].

Despite its important role as an alternative to glyphosate, glufosinate often provides a variable performance in the field. The poor performance of glufosinate in the field is often associated with its limited phloem translocation, which has been extensively studied [16,17]. Several environmental factors can influence this inconsistent response such as temperature, relative humidity, and light $[18,19]$. Therefore, glufosinate performance depends on the time of day at which the herbicide is sprayed in the field. Several papers have reported the time-of-day effect on glufosinate efficacy for several weed species [20-22]. One common observation is that glufosinate performance was lower when the herbicide was applied at either dusk or dawn compared to midday applications. While this effect has been studied for many years, little is known about the biochemical basis for such phenomenon. In this manuscript, we discuss the biochemical causes for the time-of-day effect on glufosinate performance in A. palmeri.

\section{Results}

Visual control of A. palmeri plants was compared between the application of the same glufosinate dose $\left(140 \mathrm{~g} \mathrm{ha}^{-1}\right)$ at midday $(12 \mathrm{pm})$ versus at dusk $(8 \mathrm{pm}) 21 \mathrm{~d}$ after application (Figure 1). Glufosinate treatment provided $82 \%$ visual control on average when plants were treated at midday, and only $65 \%$ when herbicide application occurred at dusk. The median percent of control was $100 \%$ for midday application compared to $68 \%$ for dusk application. This means that most plants were controlled at $100 \%$ when glufosinate was applied at midday, indicating a more consistent performance at this time of day compared to dusk application. As indicated by the violin plot, glufosinate application at dusk, provided extremely variable control of $A$. palmeri plants, and most plants were not controlled by the herbicide sprayed at this time of day. In addition, surviving plants that were treated with glufosinate at midday were more suppressed than those treated at dusk, indicating improved weed control when applications are performed in the middle of the day.

To understand the biochemical basis for the time-of-day effect, we first investigated changes in glutamine synthetase (GS1 and GS2) gene expression in different parts of an A. palmeri plant (Figure 2). In the shoot, we separated new leaves from old leaves because glufosinate tends to cause more phytotoxicity to older leaves than younger leaves. In general, GS1 expression was higher in the roots compared to the shoot, whereas GS2 expression was higher in the shoot as opposed to the roots. As expected, expression of both GS1 and GS2 was higher in the light, compared to dark conditions, especially for older leaves. Young leaves also had higher expression of GS2 in the light than in the dark. Light conditions did not affect GS1 and GS2 expression in the root tissue. 


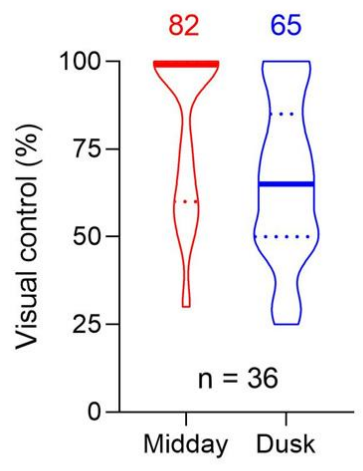

(a)

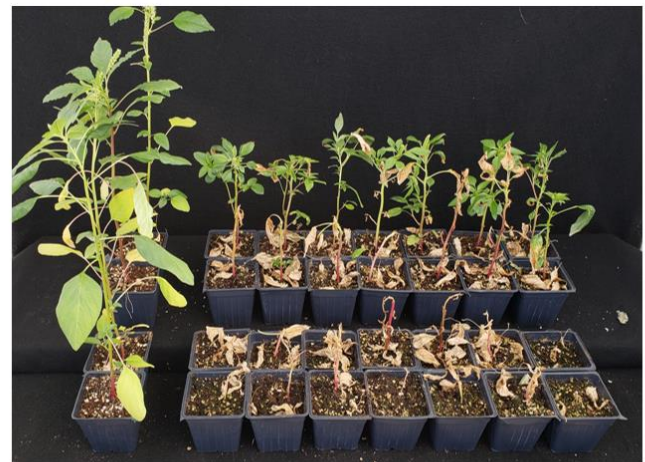

(b)

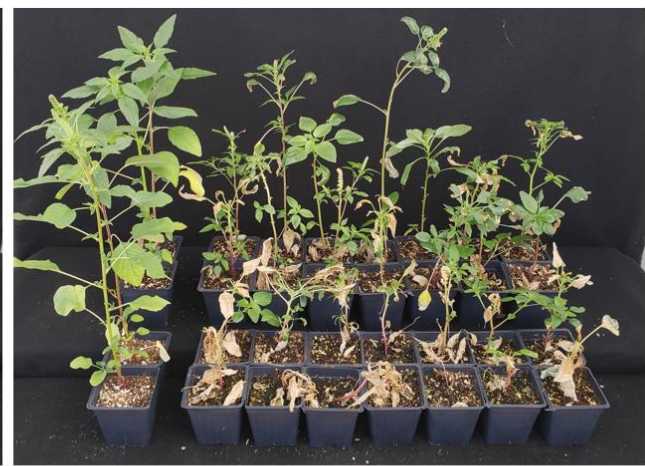

(c)

Figure 1. Violin plot (a) for \% visual control of Amaranthus palmeri by glufosinate application (140 $\mathrm{g} \mathrm{ha}^{-1}$ ) at midday (red) vs. dusk (blue). Pictures representing plant response to glufosinate application at midday (b) vs. dusk (c). Bold lines in the violin plot indicate the median, whereas the dashed lines represent the $95 \%$ confidence interval. Control plants are on the left side of each picture.

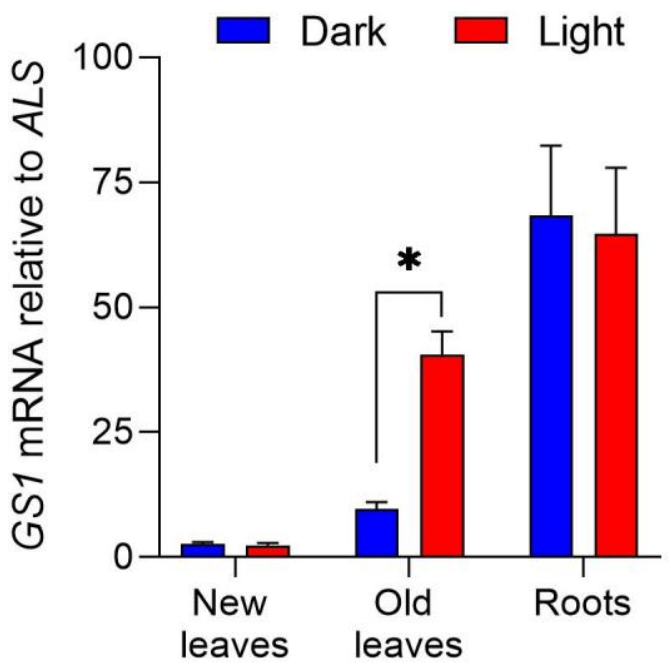

(a)

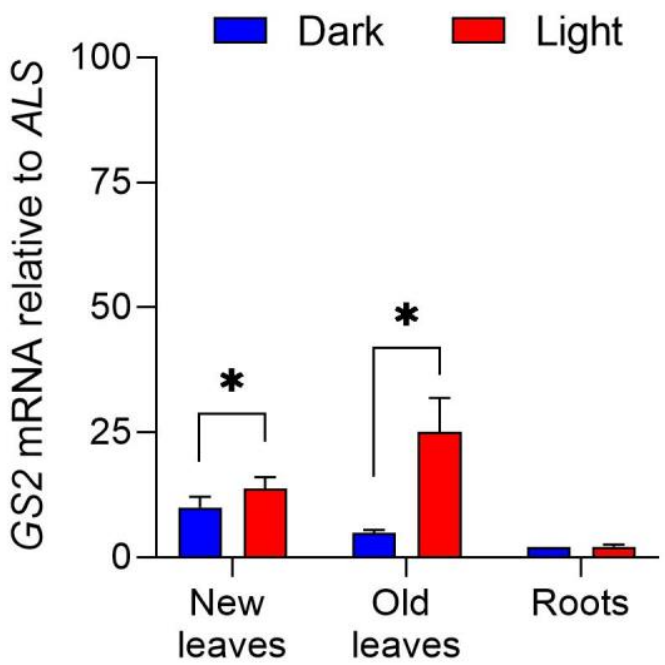

(b)

Figure 2. Glutamine synthetase (GS) genes are differentially expressed in the light compared to the dark depending on the plant tissue. GS1 (a) and GS2 (b) mRNA expression relative to ALS in new leaves, old leaves, and roots of A. palmeri plants growing in the light and in the dark. Asterisks indicate significant differences by t-test $(p<0.05)$ between light versus dark within each plant part.

GS1 and GS2 protein expression were also compared between plants growing in the light versus those in the dark (Figure 3). Plants growing in the light showed greater abundance of both GS1 and GS2 compared to the plants in the dark. Total GS protein abundance was 2-fold higher in the light compared to the dark, whereas GS2 protein levels were only 0.3-fold greater in the light. Based on both gene and protein expression data, both GS1 and GS2 of A. palmeri are more expressed and abundant in the light, compared to dark conditions. Although GS1 and GS2 expression are lower in the dark, GS protein pools remain fairly abundant even in the dark, possibly due to residual gene expression and subsequent protein translation in the light. 
(a)

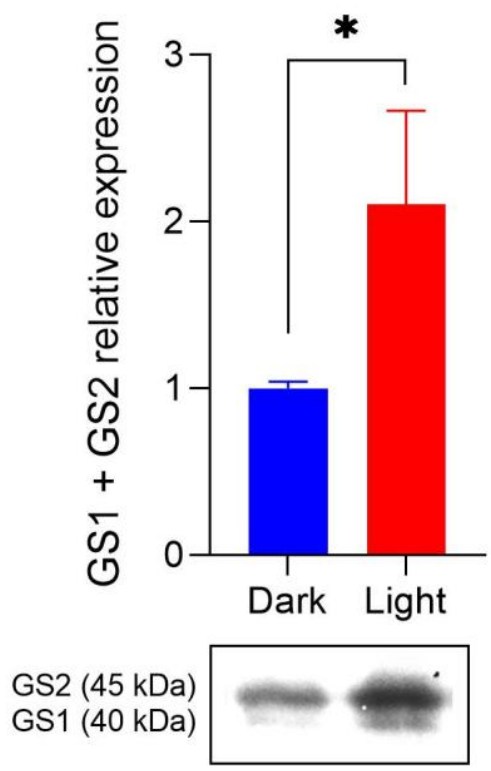

(b)

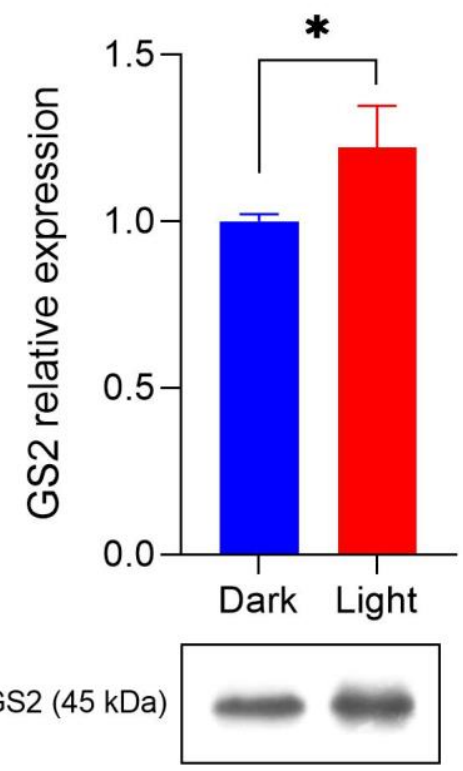

Figure 3. Glutamine synthetase (GS) protein abundance is higher in the light compared to dark incubated plants. Western blot protein expression analysis for both GS1 and GS2 (a) and for GS2 (b), the chloroplastic isoform of GS. Asterisks indicate significant differences by t-test $(p<0.05)$ between light versus dark conditions.

Finally, we investigated the turnover of glutamine synthetase (total GS activity in the plant) in response to glufosinate treatment at midday compared to dusk application (Figure 4). For midday treated plants, the development of symptoms started two hours after herbicide application progressing exponentially overtime and reaching a constant and maximum visual injury of $95 \%$ at 96 HAT. In contrast, dusk treated plants took $12-24 \mathrm{~h}$ to begin showing symptoms which were much lower than those observed with the midday application. While visual injury increased up to $60 \%$ at $72 \mathrm{HAT}$, these plants treated at dusk started to recover and regrow, allowing for them to escape glufosinate application.

The turnover of glutamine synthetase following herbicide treatment provided a clear insight onto the biochemical basis for the time-of-day effect on glufosinate efficacy (Figure $4 \mathrm{~b}$ ). Glutamine synthetase activity was inhibited at $>95 \%$ starting at 2 HAT in midday treated plants. This strong enzyme inhibition remained constant during the following days because glufosinate was able to maintain high levels of efficacy when application was performed at midday. In contrast, dusk application of glufosinate provided a maximum of $82 \%$ inhibition of glutamine synthetase between 2-24 HAT. After this period, plants were able to re-establish glutamine synthetase activity to the baseline levels, similar to the untreated plants. 
(a)

Light period for midday

Light period for dusk
Dark period for midday

Dark period for dusk
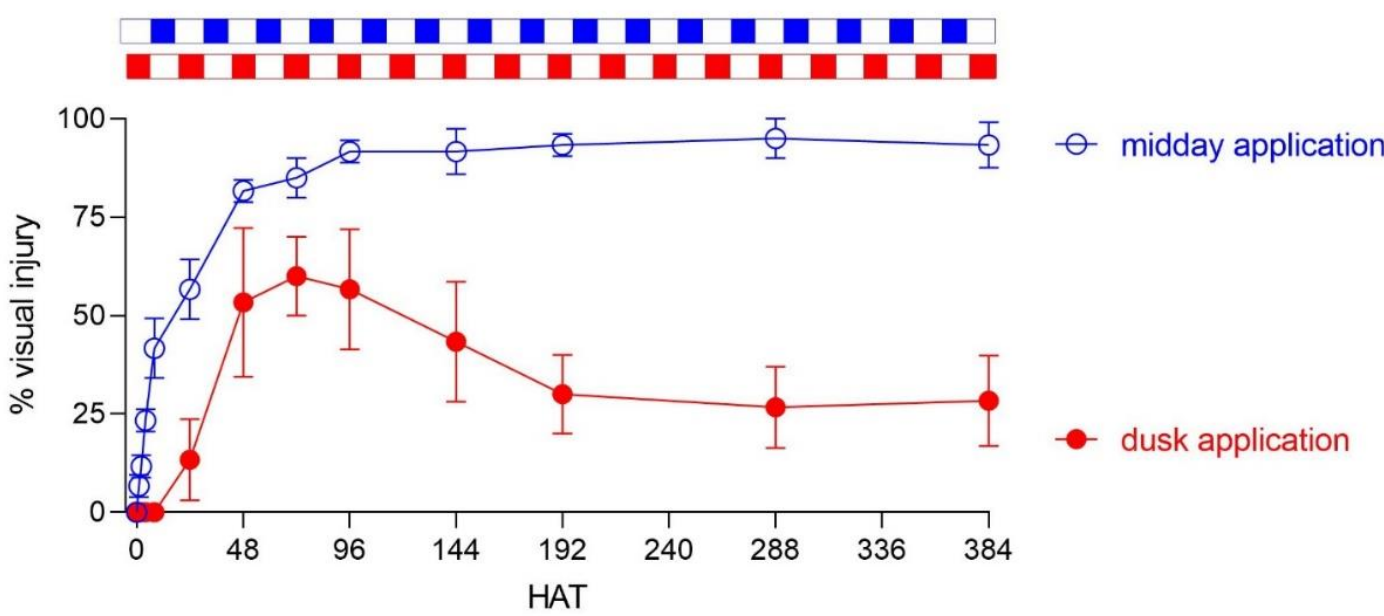

Light period for midday

Dark period for midday

Light period for dusk Dark period for dusk

(b)

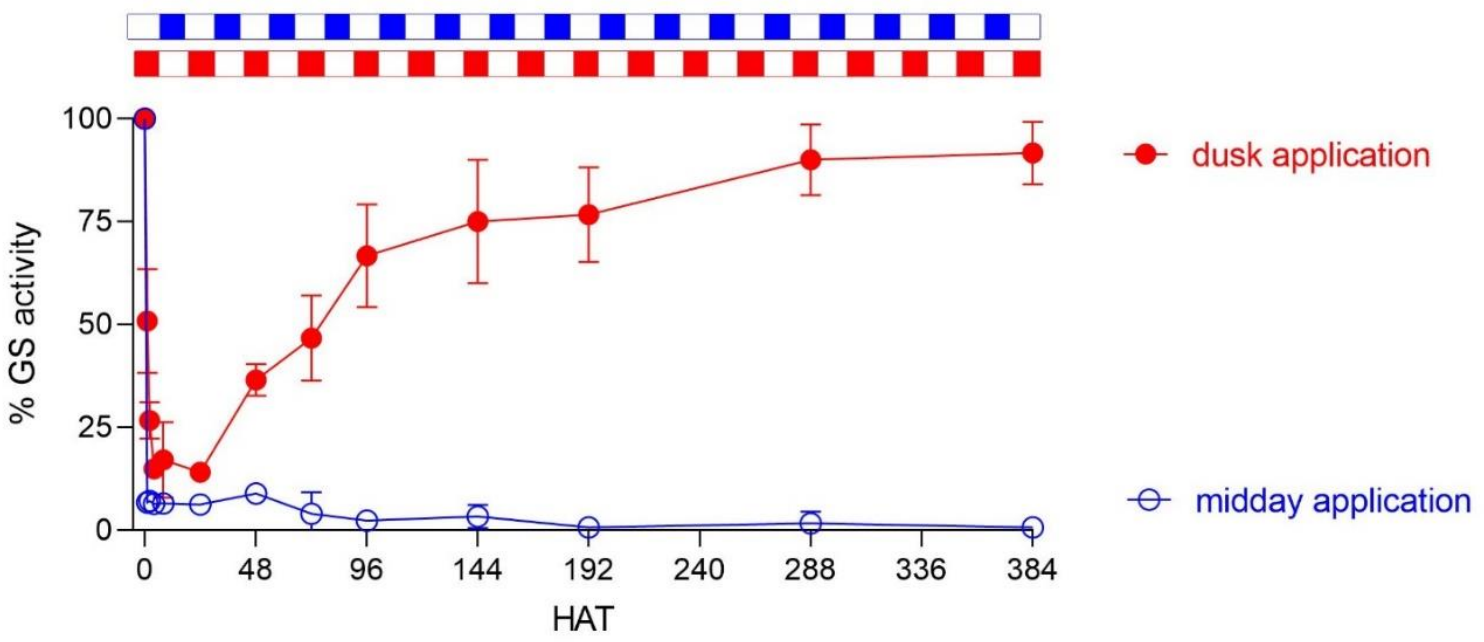

Figure 4. Turnover of glutamine synthetase (GS) total activity only occurs when glufosinate is applied at midday. Percent visual injury (a) and GS activity (b) after glufosinate application at midday (full red circle) or dusk (empty blue circle). Full squares represent daily photoperiod time for each application time (midday in blue, dusk in red). Dark periods are full squares whereas light periods are open squares.

\section{Discussion}

The time-of-day effect with glufosinate application has been known for a long time [6]. However, the biochemical basis for such observation has never been completely clear. Here, we show that the turnover of GS is responsible for glufosinate's lower performance when applied late in the afternoon (Figure 4). We hypothesize that the plants' ability to recover enzyme activity comes from de novo synthesis of GS, given that glufosinate was not able to completely control these plants when treatment occurred at dusk. This is particularly interesting because GS activity is known to be lower in the dark compared to the light in both A. palmeri (Figure 3) and other plant species [23]. In addition, GS2 is highly expressed in the leaves while GS1 is more abundant in roots (Figure 2). In C3 species such as rice, GS1 plays a crucial role on incorporating inorganic nitrogen into amino acids, while GS2 is a key enzyme on recycling ammonia from photorespiration [24]. Under full sunlight, plants 
display maximum GS activity, which keeps photorespiration ongoing. Interrupting GS activity leads to a massive light-dependent accumulation of ROS [6]. In contrast, GS activity is minimum in the dark, which makes its inhibition less damaging to photorespiration. In the dark, plants can have complete GS inhibition without apparent phytotoxicity [15].

Glufosinate is a suicide inhibitor that binds irreversibly to GS [25]. Thus, the GS enzyme pool serves as a sink for glufosinate molecules following foliar uptake even in the dark when the amount of GS protein is slightly lower than in the light (Figure 3). This "glufosinate sequestration" by GS leads to a decrease in the concentration of herbicide availability overtime. In addition, some of the glufosinate molecules may be metabolized by the plant and/or compartmentalized in the vacuole, especially when the herbicide cannot cause ROS accumulation (in the dark) [21] If the ROS-dependent rapid desiccation partially controls plants in the first days after treatment, they are able to regrow and generate more GS by de novo synthesis, allowing them to survive glufosinate treatment (Figure 4). This is what happens with dusk applications where glufosinate is unable to provide this rapid phytotoxicity following treatment because the herbicide is not active in the dark. In other words, glufosinate-treated plants at dusk can produce new GS before glufosinate can fully kill them, leading to plant survival when the herbicide is applied at dusk. Under full sunlight, however, plants suffer from a massive accumulation of ROS and rapid leaf burning. This prevents regrowth after glufosinate treatment and de novo synthesis of GS.

In conclusion, glufosinate is a light-dependent herbicide that must be applied in the hours in the middle of the day when sunlight is maximum. When glufosinate is applied in the early morning or late afternoon, or even in cloudy days, binding to GS does not lead to ROS accumulation and subsequent cellular burst with foliage desiccation. Once bound to GS, glufosinate cannot inhibit a different GS because it is a suicide inhibitor. This leads to a decreased concentration in available glufosinate molecules overtime inside the cells, which allows for plant survival and de novo synthesis of GS. Thus, glufosinate has only one chance of controlling weeds, which happens in the first few days after treatment, restricting the application to the middle hours of a sunny day for maximum performance.

\section{Materials and Methods}

\subsection{Quantification of the Time-of-Day Effect on Glufosinate Efficacy}

Seeds of Palmer amaranth (Amaranthus palmeri S. Watson) were collected in a corn field located in eastern Colorado, USA. Plants were grown in $0.3-\mathrm{cm}^{3}$ pots filled with soil (Sun Gro Horticulture, Agawam, MA, USA) until they reached $10 \mathrm{~cm}$-tall (6-8 fully expanded leaves). Environmental conditions were 25/21 C day/night, $14 \mathrm{~h}$ photoperiod (6 am-8 pm) with light intensity of $500 \mu \mathrm{mol} \mathrm{m}^{-2} \mathrm{~s}^{-1}$ and $70 \%$ relative humidity (RH). For herbicide applications, a commercial chamber track sprayer (DeVries Manufacturing, Hollandale, MN, USA) equipped with an 8002EVS single even, flat-fan nozzle (Teejet ${ }^{\mathbb{Q}}$, Spraying Systems, Denver, CO, USA) calibrated to deliver $187 \mathrm{~L} \mathrm{ha}^{-1}$ spray solution at the level of the plant canopy was used. Glufosinate commercial formulation (Liberty ${ }^{\circledR}$ $280 \mathrm{~g} \mathrm{~L}^{-1}$, BASF, Raleigh, NC, USA) was applied at $140 \mathrm{~g} \mathrm{ha}^{-1}$ with $2 \%(w / v)$ ammonium sulfate. Two growth chambers were used to mimic the time-of-day treatment. Applications were performed at noon $(12 \mathrm{pm})$ for plants in one growth chamber, or at dusk $(8 \mathrm{pm})$ in plants from the other chamber. Each treatment had 36 replications and plants were visually evaluated, where $0 \%$ means no effect and $100 \%$ plant death, at $21 \mathrm{~d}$ after treatment (DAT). The experiment was repeated in time. The datapoints were used to construct a violin plot which are similar to box plots, except that they also show the probability density of the data at different values.

\subsection{GS1 and GS2 mRNA Expression in the Light vs. Dark and Different Plant Parts}

Palmer amaranth plants were grown up to the $10 \mathrm{~cm}$-tall growth stage as described above. "Light plants" refer to those that were sampled six hours after dawn, whereas "dark plants" were harvested six hours after dusk. Plant tissue $(50 \mathrm{mg})$ was collected 
from new leaves, old leaves, and root tips, and immediately frozen in liquid nitrogen. The "new leaves" were considered as the two youngest leaves and the apical meristem, whereas "old leaves" were the oldest two fully expanded leaves in the plant. The tissue was ground using a Qiagen Tissuelyzer (Qiagen, Valencia, CA, USA). Total RNA was extracted using Qiagen RNeasy PlantMini Kit, treated with DNase I, quantified using a NanoDrop spectrophotometer (Thermo Scientific), and checked for quality and integrity with agarose gel electrophoresis (clear bands with no contamination or degradation, gels are not shown). Two hundred nanograms of RNA were used for synthesizing cDNA using Super Script cDNA synthesis kit (Thermo Scientific) with oligo-dT and random hexamers. Primers were designed for GS1, GS2 and acetolactate synthase (ALS) as internal standard: GS1_F (5' - AACCATGGTACGGTATCGAACAGG -3') and GS1_R (5'AGGCAAGCCTTGTAGTGTGAATC - $\left.3^{\prime}\right)$, GS2_F (5'- AAGGATCCATTCCGTGGTGG -3' and GS2_R (5' - TCTCAGAAACAACCTTTGGGTCG -3') [26], and ALS_F (5' - GCTGCTGAAGGCTACGCT -3') and ALS_R (5'- GCGGGACTGAGTCAAGAAGTG - $3^{\prime}$ ). Palmer amaranth cDNA (final concentration of $0.4 \mathrm{ng} \mu \mathrm{L}^{-1}$ ) was amplified using quantitative real-time polymerase chain reaction (PCR) with $25 \mu \mathrm{L}$ total volume under the following conditions: $10 \mathrm{~min}$ at $95^{\circ} \mathrm{C}, 40$ cycles of $95^{\circ} \mathrm{C}$ for $20 \mathrm{~s}$ and $59^{\circ} \mathrm{C}$ for $1 \mathrm{~min}$. After completing these cycles, temperature was $59^{\circ} \mathrm{C}$ increasing by $0.5^{\circ} \mathrm{C}$ every $5 \mathrm{~s}$ until reaching $95^{\circ} \mathrm{C}$ to obtain the melting curve. GS mRNA expression was calculated as $\Delta \mathrm{Ct}=(\mathrm{Ct}$ for ALS-Ct for GS), and the relative increase in GS expression was expressed as $2 \Delta \mathrm{Ct}$ [27]. Three biological replications were tested, and each sample was run three times to calculate the mean and standard deviation. The experiment was repeated in time and data was pooled. Results were represented as the fold increase in GS expression relative to ALS.

\subsection{GS1 and GS2 Protein Abundance in the Light Versus Dark}

Palmer amaranth plants were grown up to the $10 \mathrm{~cm}$-tall growth stage as described above. Light plants were sampled six hours after dawn, whereas dark plants were harvested six hours after dusk. Three plants of each condition were assessed. Western blot method followed protocol described elsewhere [28]. Leaf tissue (1 g) was ground in liquid nitrogen and homogenized with $2 \mathrm{~mL}$ extraction buffer composed of $50 \mathrm{mM}$ Tris (2-amino2-(hydroxymethyl)-1,3 propanediol, $\mathrm{pH} 8$ ), 2 mM EDTA (ethylmediamine tetraacetic acid), $10 \mathrm{mM}$ mercaptoethanol, $10 \%(v / v)$ glycerol. The crude extract was filtered through two layers of miracloth and clarified by centrifugation at 20,000 $\mathrm{g}$ for $30 \mathrm{~min}$. The pellets were discarded, and the supernatants were used for Western blot analysis. All steps were conducted at 4 C. The concentration of protein was estimated by the Bradford (1976) method with bovine serum albumin as a standard. Proteins were analyzed by denaturing electrophoresis in the presence of sodium dodecyl sulphate (SDS). The stacking gel was $5 \%(w / v)$ polyacrylamide $(2.5 \%$ cross-linker) and the resolving gel $12.5 \%(w / v)$ polyacrylamide ( $2.5 \%$ cross-linker). After electrophoresis, the polypeptides were visualized by staining for $2 \mathrm{~h}$ in a solution containing 1\% $(w / v)$ Coomassie blue R-250, 10\% $(v / v)$ acetic acid, $40 \%(v / v)$ methanol. The gel was extensively de-stained overnight in the same solution without the dye. Molecular masses $(\mathrm{Mr})$ in kilodaltons $(\mathrm{kDa})$ were estimated relative to a protein ladder (company). Polypeptides previously separated by SDS-polyacrylamide gel electrophoresis (PAGE) were transferred electrophoretically to a nitrocellulose membrane (Millipore, Bedford, Mans, USA) using a Multiphor II Novablot apparatus (LKB, Uppsala, Sweden). The electroblotting was conducted by the application of $0.8 \mathrm{~mA} \cdot \mathrm{cm}^{-2}$ constant current for $90 \mathrm{~min}$, and $39 \mathrm{mM}$ glycine, $48 \mathrm{mM}$ Tris, $0.04 \%(w / v)$ SDS, 20\% $(v / v)$ methanol was used as transfer buffer. The blot was processed for immunolabelling by incubation for $60 \mathrm{~min}$ in a blocking solution containing 3\% $(w / v)$ bovine serum albumin, $0.05 \%(v / v)$ Tween-20 in phosphate-buffered saline (PBS; $140 \mathrm{mM} \mathrm{NaCl}, 3 \mathrm{mM} \mathrm{KCl}, 5 \mathrm{mM} \mathrm{Na}_{2} \mathrm{HPO}_{4}$; $\mathrm{pH}$ 7.4). The filter was then incubated overnight with GS1/GS2 (Agrisera, AS08295) or GS2 (Agrisera, AS08296) antibodies raised against GS from Arabidopsis thaliana. A 1:1000 dilution in $0.5 \%(w / v)$ bovine serum albumin, $0.02 \%(v / v)$ Tween-20, PBS, was the working solution. Finally, the nitrocellulose sheet was washed another three times with PBS and the 
peroxidase activity viewed by incubation in $0.02 \%(v / v) \mathrm{H}_{2} \mathrm{O}_{2}, 4 \mathrm{mM}$ 4-chloro-1-naphthol in PBS. The enzymatic reaction was stopped by two washes with distilled water. The Western blots were wrapped in aluminum foil until photographed. The gel image was then converted to gray scale and reverted. Protein bands were quantified by measuring their relative intensity using photoshop (Adobe Photoshop, v.22.4.3).

\subsection{The Turnover of Glutamine Synthetase Activity Following Glufosinate Treatment}

A. palmeri plants were grown and sprayed at midday or dusk as described above. In total, six replications were used for each timepoint, and the experiment was repeated in time. Visual injury and glutamine synthetase enzyme activity were evaluated at 1, 2, 4, 12, $24,48,72,96,144,192,288$ and $384 \mathrm{~h}$ after treatment (HAT). In planta glutamine synthetase activity was quantified by the GS-dependent formation of $\gamma$-glutamyl hydroxamate by measuring the transferase activity [29]. Similar doses, growth stage, number of replications, and spray settings from glufosinate dose response section were used for this assay. Eight HAT, $2 \mathrm{~g}$ of leaf material was collected and homogenized in a chilled mortar with $3 \mathrm{~mL}$ of extraction buffer. The extraction buffer $(\mathrm{pH} 8)$ consisted of $50 \mathrm{mM}$ Tris base, $1 \mathrm{mM}$ EDTA, $2 \mathrm{mM}$ DTT, $10 \mathrm{mM} \mathrm{MgCl}_{2}$, and 50\% $(w / v)$ PVP10. The extract was then filtered through miracloth layered on top of cheesecloth after washing the mortar with additional $1 \mathrm{~mL}$ extraction buffer. The filtered extract was centrifuged at $12,000 \times \mathrm{g}$ for $10 \mathrm{~min}$ at $4{ }^{\circ} \mathrm{C}$. The reaction consisted of $0.9 \mathrm{~mL}$ of assay buffer and $0.1 \mathrm{~mL}$ of crude enzyme extract, incubated for $30 \mathrm{~min}$ at $30^{\circ} \mathrm{C}$. The assay buffer consisted of $25 \mathrm{mM}$ imidazole- $\mathrm{HCl}$ (pH 7.5), $4 \mathrm{mM} \mathrm{MnCl}_{2}, 5 \mathrm{mM}$ ADP, $50 \mathrm{mM}$ L-glutamine, $40 \mathrm{mM}$ sodium arsenate, and $25 \mathrm{mM}$ hydroxylamine. To stop the reaction, $0.5 \mathrm{~mL}$ ferric chloride reagent was added, and the mixture was incubated for $10 \mathrm{~min}$ at room temperature, followed by centrifugation at $12,000 \times g$ for $10 \mathrm{~min}$. The ferric chloride reagent consisted of $32 \%(w / v)$ anhydrous ferric chloride dissolved in $0.5 \mathrm{M} \mathrm{HCl}$. The concentration of $\gamma$-glutamyl hydroxamate was determined by measuring absorbance at $540 \mathrm{~nm}$ on a spectrophotometer (SynergyTM 2 Multi-Mode Microplate Reader; BioTek, Winooski, VT, USA).

\subsection{Data Analysis}

Statistical analysis was performed in R software (v.4.1.0, The R Foundation) All data passed normality by visual inspection of normality plots, and homogeneity of variances by Levene's test. The means for GS1 and GS2 mRNA expression and for GS1 and GS2 protein abundance were compared by t-test $(\mathrm{P}<0.05)$. The other data were graphed and represented as the mean \pm standard deviation. All graphing were performed with Prism software (GraphPad v. 8.3.1, San Diego, CA, USA).

Author Contributions: Conceptualization, H.K.T. and F.E.D.; data curation, H.K.T. and F.E.D.; writing — original draft preparation, H.K.T.; writing—review and editing, F.E.D.; funding acquisition, F.E.D. All authors have read and agreed to the published version of the manuscript.

Funding: This research was funded by BASF Corporation and the USDA National Institute of Food and Agriculture, Hatch Project 1016591, COL00785.

Conflicts of Interest: The authors declare no conflict of interest.

\section{References}

1. Cren, M.; Hirel, B. Glutamine synthetase in higher plants regulation of gene and protein expression from the organ to the cell. Plant Cell Physiol. 1999, 40, 1187-1193. [CrossRef]

2. Unno, H.; Uchida, T.; Sugawara, H.; Kurisu, G.; Sugiyama, T.; Yamaya, T.; Sakakibara, H.; Hase, T.; Kusunoki, M. Atomic structure of plant glutamine synthetase: A key enzyme for plant productivity. J. Biol. Chem. 2006, 281, 29287-29296. [CrossRef]

3. Oliveira, I.C.; Brears, T.; Knight, T.J.; Clark, A.; Coruzzi, G.M. Overexpression of cytosolic glutamine synthetase. Relation to nitrogen, light, and photorespiration. Plant Physiol. 2002, 129, 1170-1180. [CrossRef]

4. Edwards, J.W.; Walker, E.L.; Coruzzi, G.M. Cell-specific expression in transgenic plants reveals nonoverlapping roles for chloroplast and cytosolic glutamine synthetase. Proc. Natl. Acad. Sci. USA 1990, 87, 3459-3463. [CrossRef] [PubMed]

5. Keys, A.J. The re-assimilation of ammonia produced by photorespiration and the nitrogen economy of $\mathrm{C} 3$ higher plants. Photosyn. Res. 2006, 87, 165-175. [CrossRef] [PubMed] 
6. Takano, H.K.; Dayan, F.E. Glufosinate-ammonium: A review of the current state of knowledge. Pest Manag. Sci. 2020, 76, 3911-3925. [CrossRef]

7. Takano, H.K.; Beffa, R.; Preston, C.; Westra, P.; Dayan, F.E. A novel insight into the mode of action of glufosinate: How reactive oxygen species are formed. Photosyn. Res. 2020, 144, 361-372. [CrossRef] [PubMed]

8. Droge-Laser, W.; Siemeling, U.; Puhler, A.; Broer, I. The metabolites of the herbicide L-phosphinothricin (glufosinate): Identification, stability, and mobility in transgenic, herbicide-resistant, and untransformed plants). Plant Physiol. 1994, 105, 159-166. [CrossRef] [PubMed]

9. Gill, H.S.; Eisenberg, D. The crystal structure of phosphinothricin in the active site of glutamine synthetase illuminates the mechanism of enzymatic inhibition. Biochemistry 2001, 40, 1903-1912. [CrossRef] [PubMed]

10. Merchant, R.M.; Culpepper, A.S.; Eure, P.M.; Richburg, J.S.; Braxton, L.B. Controlling glyphosate-resistant Palmer amaranth (Amaranthus palmeri) in cotton with resistance to glyphosate, 2, 4-D, and glufosinate. Weed Technol. 2014, 28, 291-297. [CrossRef]

11. Heap, I. The International Survey of Herbicide Resistant Weeds. 2021. Available online: www.weedscience.org (accessed on 14 July 2021).

12. Brunharo, C.A.; Takano, H.K.; Mallory-Smith, C.A.; Dayan, F.E.; Hanson, B.D. Role of glutamine synthetase isogenes and herbicide metabolism in the mechanism of resistance to glufosinate in Lolium perenne L. spp. multiflorum biotypes from Oregon. J. Agric. Food Chem. 2019, 67, 8431-8440. [CrossRef]

13. De Block, M.; Botterman, J.; Vandewiele, M.; Dockx, J.; Thoen, C.; Gossele, V.; Movva, N.R.; Thompson, C.; Van Montagu, M.; Leemans, J. Engineering herbicide resistance in plants by expression of a detoxifying enzyme. EMBO J. 1987, 6, 2513-2518. [CrossRef]

14. Braz, G.B.P.; Oliveira, R.S., Jr.; Constantin, J.; Raimondi, M.A.; Franchini, L.H.M.; Biffe, D.F.; Arantes, J.G.Z.; Takano, H.K. Selectivity of ammonium-glufosinate applied alone or in mixture with pyrithiobac sodium in transgenic LL®cotton. Planta Daninha 2012, 30, 853-860. [CrossRef]

15. Takano, H.K.; Beffa, R.; Preston, C.; Westra, P.; Dayan, F.E. Reactive oxygen species trigger the fast action of glufosinate. Planta 2019, 249, 1837-1849. [CrossRef]

16. Kumaratilake, A.R.; Preston, C. Low temperature reduces glufosinate activity and translocation in wild radish (Raphanus raphanistrum). Weed Sci. 2005, 53, 10-16. [CrossRef]

17. Takano, H.K.; Beffa, R.; Preston, C.; Westra, P.; Dayan, F.E. Physiological factors affecting uptake and translocation of glufosinate. J. Agric. Food Chem. 2020, 68, 3026-3032. [CrossRef] [PubMed]

18. Petersen, J.; Hurle, K. Influence of climatic conditions and plant physiology on glufosinate-ammonium efficacy. Weed Res. 2001, 41, 31-39. [CrossRef]

19. Takano, H.K.; Beffa, R.; Preston, C.; Westra, P.; Dayan, F.E. Glufosinate enhances the activity of protoporphyrinogen oxidase inhibitors. Weed Sci. 2020, 68, 324-332. [CrossRef]

20. Martinson, K.B.; Durgan, B.R.; Gunsolus, J.L.; Sothern, R.B. Time of day of application effect on glyphosate and glufosinate efficacy. Crop Manag. 2005, 4, 1-7. [CrossRef]

21. Sellers, B.A.; Smeda, R.J.; Li, J. Glutamine synthetase activity and ammonium accumulation is influenced by time of glufosinate application. Pestic. Biochem. Physiol. 2004, 78, 9-20. [CrossRef]

22. Cánovas, F.M.; Avila, C.; Botella, J.R.; Valpuesta, V.; de Castro, I.N. Effect of light-dark transition on glutamine synthetase activity in tomato leaves. Physiol. Plant. 1986, 66, 648-652. [CrossRef]

23. Aliverdi, A.; Ahmadvand, G.; Emami-Namivandi, B. Weed control of glufosinate, oxyfluorfen, and paraquat as affected by the application time of day. Planta Daninha 2020, 38, e020221613. [CrossRef]

24. Salas-Perez, R.A.; Saski, C.A.; Noorai, R.E.; Srivastava, S.K.; Lawton-Rauh, A.L.; Nichols, R.L.; Roma-Burgos, N. RNA-Seq transcriptome analysis of Amaranthus palmeri with differential tolerance to glufosinate herbicide. PLoS ONE 2018, 13, e0195488.

25. Takano, H.K.; Fernandes, V.N.; Adegas, F.S.; Oliveira, R.S., Jr.; Westra, P.; Gaines, T.A.; Dayan, F.E. A novel TIPT double mutation in EPSPS conferring glyphosate resistance in tetraploid Bidens subalternans. Pest Manag. Sci. 2020, 76, 95-102. [CrossRef]

26. Habash, D.Z.; Massiah, A.J.; Rong, H.L.; Wallsgrove, R.M.; Leigh, R.A. The role of cytosolic glutamine synthetase in wheat. Annals Appl. Biol. 2001, 138, 83-89. [CrossRef]

27. Forlani, G. Purification and properties of a cytosolic glutamine synthetase expressed in Nicotiana plumbaginifolia cultured cells. Plant Physiol. Biochem. 2000, 38, 201-207. [CrossRef]

28. Hirel, B.; Gadal, P. Glutamine synthetase in rice: A comparative study of the enzymes from roots and leaves. Plant Physiol. 1980, 66, 619-623. [CrossRef] [PubMed]

29. Lacuesta, M.; González-Moro, B.; González-Murua, C.; Aparicio-Tejo, P.; Muñoz-Rueda, A. Effect of phosphinothricin (glufosinate) on activities of glutamine synthetase and glutamate dehydrogenase in Medicago sativa L. J. Plant Physiol. 1989, 134, 304-307. [CrossRef] 